A N N A L E S

UNIVERSITATIS MARIAE CURIE-SKŁODOWSKA

LUBLIN - POLONIA

VOL. XXXII, 4

SECTIO J

2019

Uniwersytet Zielonogórski. Wydział Pedagogiki, Psychologii i Socjologii

\title{
INETTA NOWOSAD
}

ORCID: 0000-0002-3739-7844

inettanowosad@wp.pl

\section{Innowacje i przedsiębiorczość w szkole jako odpowiedź na wyzwania zmieniającego się świata}

Innovation and Entrepreneurship at School as a Response to the Challenges of the Changing World

\section{STRESZCZENIE}

Zmiany, jakie nastąpiły w otoczeniu szkoły, stają się dla niej wyzwaniem. W niniejszym opracowaniu zwrócono uwagę na dwie kategorie innowacji i przedsiębiorczości, analizując je jako kluczowe nie tylko w przygotowaniu uczniów do wejścia w dorosłe życie (w tym w życie zawodowe), lecz także jako warunek odnowy szkoły. Dokonując przeglądu literatury (zarówno polskiej, jak i zagranicznej), przywołano argumenty uzasadniające przyjęte przez autorkę stanowisko.

Słowa kluczowe: innowacje; przedsiębiorczość; rozwój szkoły

\section{WPROWADZENIE}

Aby szkoła miała szansę na uczestniczenie w przygotowaniu uczniów do wejścia w życie dorosłe (w tym w życie zawodowe), musi otworzyć się na zmieniające się warunki otoczenia. Nie jest już zaskoczeniem, że przewagę w świecie zdobywa nie ten, kto umie produkować, lecz ten, kto jest zdolny wymyślać nowe produkty i korzystać z wiedzy. Kieruje to uwagę na potencjał innowacji, które wywodząc się z wiedzy, zdolne są przekształcać świat. Nacisk na „odkrywanie tego, co jest możliwe”, odzwierciedla przejście z „epoki informacji” do „wieku innowacji”. Jest to czas, w którym nowe pomysły przebijają wartość wiedzy i stają się najcenniejszym towarem. Eksperci OECD uważają, że tendencja do praktykowania innowacji w edukacji wynika z czterech głównych źródeł: 
- presji społecznej i ekonomicznej, by poprawić (podnieść) osiągnięcia uczniów,

- zmian, jakie dokonały się w środowisku pracy, życiu społecznym i rodzinnym,

- szybko rozwijających się technologii,

- potrzeby motywowania i angażowania uczniów, wzmacniającej efektywność procesów dydaktycznych (Looney, 2009, s. 4-5).

W efekcie tego presja wywierana na szkoły ma pomóc w rozwoju innowacyjnych środowisk edukacyjnych, adekwatnych do specyficznego kontekstu, w którym funkcjonują. Warto zauważyć, że współcześnie mało którym kategoriom przypisuje się tak znaczącą rolę, jak innowacjom. W polityce Unii Europejskiej i jej priorytetach znaczenie innowacji dla rozwoju od lat jest wyraźnie podkreślane w różnej rangi dokumentach (Przyborowska, 2013, s. 17) i jest wzmacniane takimi programami badawczymi, jak np. „Horyzont 2020” - największy na świecie wielonarodowy program badawczy. Wszystko po to, by utrzymać Europę w czołówce innowacji wdrażanych na świecie.

Otwarcie szkół na potencjał edukacyjny istniejący poza jej murami ukazuje niewykorzystane możliwości powiązania edukacji z zasobami rynku, które nie powinny być odbierane jako wyłączna domena szkolnictwa zawodowego. Dlatego ważną kwestią, poza umacnianiem istniejącej struktury instytucji przygotowujących uczniów do wyboru zawodu, jest wspieranie innowacyjnych form tego przygotowania. Związek ten wydaje się o wiele silniejszy, ponieważ trwały rozwój gospodarczy krajów wysoko rozwiniętych wykazuje ścisłe powiązanie z edukacją i jest tak samo ważny i eksponowany na różnych etapach życia człowieka. Zjawisko to można też ując inaczej - otóż podstawą rozwoju gospodarczego jest system edukacji dobrze dopasowany do wymagań rynku pracy. Rynek pracy jest bowiem zależny od zmian stanu gospodarki, ta zaś może być dynamizowana przez edukację organizowaną stosownie do potrzeb (aktualnych i przyszłych). W tej powszechnie akceptowanej już triadzie niepokojące są rezultaty badań podejmowanych zarówno przez społeczność międzynarodową, jak i zespoły krajowe, które w wielu krajach wykazują niedostosowanie formalnej edukacji do rynku pracy. Jest to dystans, który wyraźnie zaznacza się również w naszym kraju. Pokonanie tego impasu skupia uwagę zarówno na poszukiwaniu inicjatyw zorientowanych na zacieśnienie współpracy między szkołą a rynkiem pracy, jak i na zapewnieniu absolwentom wiedzy i umiejętności oczekiwanych przez firmy poprzez wyposażenie ich w niezbędne kompetencje ułatwiające im proces przejścia z edukacji na rynek pracy.

Podejmowane w wielu krajach inicjatywy eksponują znaczenie przedsiębiorczości w rozwiązywaniu takich problemów społecznych, jak np. bezrobocie, poprzez tworzenie miejsc pracy i kierują uwagę na politykę oświatową krajów zainteresowanych jej rozwojem w instytucjach formalnej edukacji. Można nawet zaryzykować stwierdzenie, że inicjatywy wspierające przedsiębiorczość w szkole wpisują się w koncepcję innowacji politycznej, która stanowi świadectwo okre- 
ślonych zmian i rozwoju ${ }^{1}$. Na tym polu inicjatywy ministerialne wpisują się coraz częściej w podejmowane reformy oświatowe ukierunkowane na tworzenie nowoczesnej gospodarki.

Przegląd literatury światowej zwraca uwagę na potrzebę zrozumienia zjawiska przedsiębiorczości, a badania naukowe w tej dziedzinie nabierają rozmachu i są podejmowane na całym świecie (Fayolle, Gailly, Lassas-Clerc, 2006; Gürol, Atsan, 2006, s. 25; Fayolle, Gailly, 2008, s. 569). Można przyjąć, że przedsiębiorczość jest nową, rozwijającą się dziedziną badań naukowych i edukacji, która została zainicjowana przez badania podjęte w 1945 r. w Harvard Business School (Kirby, 2004, s. 510). Od tego czasu znaczenie kształtowania przedsiębiorczości jako postawy wobec życia tylko rosło na znaczeniu i współcześnie jest rozumiane jako znaczący czynnik przyspieszenia rozwoju gospodarczego poprzez generowanie nowych pomysłów lub przekształcanie ich w rentowne i dochodowe przedsięwzięcia (Tucker, Selcuk, 2009, s. 142). Można nawet przyjąć, że koncepcje kształcenia w zakresie przedsiębiorczości stały się ważnym zjawiskiem społecznym i gospodarczym oraz istotnym przedmiotem badań i zainteresowań naukowców (Fayolle, Gailly, 2008, s. 569). Wymiernym dowodem tego zainteresowania jest szereg badań analizujących rozwój i stan edukacji w zakresie przedsiębiorczości (Garavan, O’Cinneide, 1994; Kuratko, 2003).

Celem niniejszego artykułu uczyniono ogląd dwóch kategorii - przedsiębiorczości i innowacyjności - w odniesieniu do szkoły jako miejsca inicjującego związek edukacji i gospodarki w przygotowaniu młodych ludzi do satysfakcjonującego i produktywnego życia. W tym ujęciu przywołane w tytule kategorie innowacji i przedsiębiorczości w odniesieniu do środowiska szkolnego są rozumiane jako wzmacnianie zdolności innowacyjnej szkoły w procesie rozwoju przedsiębiorczej kultury szkoły. Dzieje się tak, gdy poszczególne obszary szkoły (procesy nauczania-uczenia się, obszar personalny i organizacyjny) pozostają każdorazowo w ścisłym związku z innowacyjnością. Na znaczeniu zyskują wówczas: komunikacja, uczenie się, zarządzanie wiedzą oraz równowaga pomiędzy pracą a życiem prywatnym. Siła innowacyjności szkoły jest tu postrzegana jako podjęcie działań perspektywicznych (przewidujących) przez całą społeczność szkolną (w tym uczniów) w intensywnie zmieniających się warunkach zewnętrznych (pozaszkolnych).

\section{PRZEDSIĘBIORCZOŚĆ - WIELOWYMIAROWOŚĆ POJĘCIA}

Przedsiębiorczość może być rozpatrywana jako postawa, z którą łączy się grupa predyspozycji psychospołecznych. Takie rozumienie wynika z analizy definicji stosowanych w literaturze i może być analizowane z wielu perspektyw:

1 Analiza porównawcza w oparciu o koncepcję innowacji politycznej Manfreda Rürupa została zastosowana przez Inettę Nowosad w badaniu autonomii szkół publicznych w Niemczech (por. Nowosad, 2008). 
ekonomicznej, psychologicznej, kulturowej. Sytuacja ta sprawia, że przedsiębiorczość znajduje się na styku wielu dyscyplin, których rozważania koncentrują się na jednostce $\mathrm{i}$ jej funkcjonowaniu w społeczeństwie. W teorii zarządzania przedsiębiorczość jest najczęściej opisywana jako cecha charakteru lub zespół cech w grupie i zachowań właściwych przede wszystkim dla przedsiębiorców, eksponując działania zmierzające do zapewnienia racjonalnej i efektywnej koordynacji zasobów gospodarczych firmy. Przedsiębiorczość jest „,echą organizacji, drogą jej rozwoju, ale także cechą człowieka" (Karney, 2007, s. 144). Przyjęcie takiej perspektywy daleko wykracza poza wąskie interpretacje sprowadzające przedsiębiorczość do zachowań i cech ,przedsiębiorcy”, czyli osoby prowadzącej działalność gospodarczą. Ze względu na potrzeby edukacji szkolnej zasadne wydaje się rozumienie przedsiębiorczości w szerokim ujęciu jako „zorganizowany proces sekwencyjnych działań, ukierunkowany w danych warunkach na występujące ryzyko, na wykorzystanie nowatorskiego pomysłu w celu generowania korzyści na rynku" (Adamczyk, 1995, s. 13).

W teorii ekonomii przedsiębiorczość definiowana jest jako swoista forma pracy lub jako czwarty (obok pracy, ziemi i kapitału) czynnik produkcji. Główne cechy przedsiębiorców to przede wszystkim umiejętność dostrzegania potrzeb i doskonalenia pomysłów, zdolność do wykorzystywania nadarzających się okazji oraz gotowość do podejmowania ryzyka. W opracowaniach Josepha Schumpetera - twórcy teorii rozwoju gospodarczego - przedsiębiorczość jest ściśle powiązana z koncepcją innowacji, obie zaś stanowią integralną część teorii rozwoju gospodarczego. Zasadnicze cechy przedsiębiorczości to „umiejętność dostrzegania potrzeb i doskonalenia pomysłów oraz gotowość do podejmowania ryzyka" (Encyklopedia ..., 1997, s. 361).

W socjologii badacze podkreślają istotę korzystania z kapitału przez jednostkę. Zwracają przy tym uwagę na fakt, że kapitałem mogą być również wiedza, umiejętności, doświadczenie. Marek Ziółkowski, analizując przedsiębiorczość, posługuje się dychotomiami aktywność - bierność, produktywność - receptywność oraz wyróżnia przedsiębiorczość innowacyjną i przedsiębiorczość zachowawczą. Dalej zaś różnicuje je na kooperacyjną, prospołeczną, egocentryczną i wyzysku (za: Gołdyka, 1999, s. 227). Przedsiębiorczość przejawia się zatem inicjatywą w podejmowaniu różnych działań, twórczym podejściem do otaczającej nas rzeczywistości oraz zdolnością do dbania o zaspokojenie własnych potrzeb. Przyjęcie stanowiska, że przedsiębiorczość to postawa motywowana potrzebą osiągnięć, skłania do szerszej refleksji, mianowicie ludzie przedsiębiorczy nie tylko skutecznie realizują własne cele, lecz także kształtują obraz społeczeństwa.

Współczesne rozważania wokół przedsiębiorczości czynią z niej bardzo pojemną kategorię, wykraczającą daleko poza perspektywę ekonomiczną, ponieważ $\mathrm{w}$ jej analizie istotne jest uwzględnienie szerokiego kontekstu przemian w gospodarce związanych ze zmianami w kulturze (Gołdyka, 1999, s. 227). Cédric 
D. Lavoie za działania przedsiębiorcze przyjął wykorzystywanie tych możliwości uzyskania korzyści, których inne jednostki nie dostrzegły: „Sukces jest rozumiany jako przejmowanie inicjatywy, wyczucie i wykorzystywanie obiektywnie istniejących sytuacji. (...) kultura wyznacza jedynie rodzaje dóbr przedkładanych w określonym społeczeństwie nad inne" (za: Gołdyka, 1999, s. 229). Istotne jest zatem subiektywne znaczenie tych dóbr, nie zaś obiektywne okoliczności gospodarcze i procesy przyczynowo-skutkowe badane przez ekonomistów. Ponadto Lavoie uważa, że kultura to zespół okoliczności kształtujących kontekst procesów gospodarczych uruchamianych przez przedsiębiorczość, a nie te procesy. Postawa przedsiębiorcza jest dla tego badacza powiązana z kulturą, a tym samym całkowicie jest przez nią ukształtowana.

Przedsiębiorczość to nic innego jak interpretowanie kultury i wpływanie na nią. (...) Dostrzeganie okazji jest kwestią kulturowej interpretacji. Jak w każdej innej interpretacji, owo odczytywanie odbywa się w szerszym kontekście znaczeń, jest zakorzenione w praktyce dyskursu - słowem w kulturze. Inaczej mówiąc, to nie domena odosobnionego, niezależnego oryginała, który dostrzega możliwość zysku w sytuacjach, które inni potraktowali obojętnie. Przedsiębiorczość to nastawienie człowieka głęboko zanurzonego w swojej kulturze, który potrafi szybko zrozumieć, o czym toczy się rozmowa. (za: Gołdyka, 1999, s. 330)

Dokonując analizy istniejących stanowisk, Andrzej Janowski (1998) w słowniku ekonomicznym przyjął, że o przedsiębiorczości można mówić w dwóch wymiarach:

1. Procesualnym, eksponując akt tworzenia i budowanie czegoś nowego, nowego przedsiębiorstwa, wówczas przedsiębiorczość stanowi zorganizowany proces działań ukierunkowany w danych warunkach na wykorzystanie nowatorskiego pomysłu w celu generowania korzyści na rynku. W tak zorientowanym procesie eksponowane są: kreatywność i innowacje, umiejętność wykorzystania pomysłów, okazji, ryzyko lub inaczej umiejętność radzenia sobie z niepewnością.

2. Jako zespół cech opisujących szczególny sposób postępowania człowieka. Wówczas przedsiębiorczość wyróżnia się dynamizmem, aktywnością, skłonnością do podejmowania ryzyka, umiejętnością przystosowywania się do zmieniających się warunków, postrzeganiem szans i ich wykorzystywaniem, innowacyjnością i motoryką.

Pod pojęciem ,przedsiębiorczość” można zatem rozumieć taką postawę, która umożliwia zdolność rozpoznawania i wykorzystywania szans; inaczej mówiąc, jest to podejmowanie się działalności, „przed-się-wzięcie” czegoś. Z tego założenia wynika, że przedsiębiorczość to nie czynność przedsiębiorcy sama w sobie, lecz jego działanie i zachowanie się w ogóle, wynikające zarówno z zespołu cech osobowych człowieka, jak i z aktywnego uczestnictwa w życiu społeczno-gospo- 
darczym i kulturowym, dające w efekcie dużo satysfakcji i zadowolenia. Interesujące jest, że przedstawiane współcześnie koncepcje człowieka nowoczesnego eksponują ścisły związek z postawą przedsiębiorczą. We wszystkich opracowaniach najważniejszą cechą człowieka nowoczesnego jest bowiem odczuwanie potrzeby zmian (otwartość na zmianę), która przejawia się w wykazywaniu predyspozycji do przyjmowania nowych idei, nowych sposobów działania. Jednocześnie odrzuca się stare schematy i zastępuje je nowymi doświadczeniami. Człowiek nowoczesny jest świadom konieczności zaakceptowania zmiany społecznej.

Peter F. Drucker podaje, że przedsiębiorczość to zachowanie lub cecha: „,...) sprowadza się [ona - I.N.] do gotowości i zdolności podejmowania i rozwiązywania w sposób twórczy i nowatorski nowych problemów, umiejętności, wykorzystywania pojawiających się szans i okazji do elastycznego przystosowania się do zmieniających się warunków funkcjonowania gospodarki” (za: Kwiatkowski, 2000, s. 55). Inaczej rzecz ujmując, przedsiębiorczość „to sposób działania, polegający na skłonności podejmowania nowych, ryzykownych i niekonwencjonalnych przedsięwzięć oraz na wykazywaniu inicjatywy w ich poszukiwaniu i wdrażaniu w życie. Jest to więc działanie skierowane na rozwój, ma ono charakter innowatorski" (Kortana, 1997, s. 77-78).

Przedstawione ujęcia pozwalają na konkluzję, iż przedsiębiorczość nie polega na uzyskiwaniu maksimum korzyści z wykorzystywania tego, co istnieje, lecz na ciągłym stwarzaniu czegoś nowego - wówczas można przyjąć, że jest utożsamiana z innowatorstwem (zob. Hasło: przedsiębiorczość). „Przedsiębiorczość jest podstawą i warunkiem innowacyjnego rozwoju gospodarki, podnoszenia życia społeczeństwa oraz indywidualnej zamożności. Zapewnia wzrost dochodów ludności, a zwłaszcza przedsiębiorczych" (Koch, 1997). Jeszcze prościej ujął to Drucker (1992), podkreślając, że przedsiębiorczość polega na współzależności działań przedsiębiorczych i innowacyjnych prowadzących do sukcesu.

Przedsiębiorczość nie musi być wyłączną domeną przedsiębiorstw, równie dobrze może odnosić się do gospodarstw domowych, instytucji administracyjnych i innych sfer codziennych ludzkich kontaktów. W odniesieniu do szkoły potrzeba kształtowania ludzi przedsiębiorczych odzwierciedla istniejące dążenie do kreowania szkoły wychowującej, w której uczeń - obok zdobywania wiedzy funkcjonalnej i umiejętności - kształtuje swoje postawy i zachowania zgodnie z duchem czasów.

\section{INNOWACJE W EDUKACJI}

Jak stwierdził Bogdan Śliwerski:

(...) innowacja edukacyjna ma miejsce wówczas, gdy w grę wchodzi staranie o to, by stworzyć nowe, odmienne wartości, nowe i odmienne sposoby zaspokajania potrzeb, przekształcić „materiał” (instytucje, jej infrastrukturę, podmioty edukacji itp.) w „zasób” lub połączyć istniejące zasoby 
w nową, bardziej efektywną konfigurację. Mamy wówczas do czynienia z morfogenezą, zmianą porządku, czyli procesem przenikającym do najtrwalszych poziomów, włączając schematy interpretatywne. (Śliwerski, 2008, s. 110)

Inicjatorzy innowacji muszą więc odczuwać potrzebę korzystania z niej i widzieć w niej szansę dla siebie (Drucker, 2002, s. 406). Według Druckera jest to możliwe po spełnieniu pięciu podstawowych warunków, typowych dla celowej i systematycznej innowacji (Drucker, 2002, s. 405-408). Są to:

1. Analiza szans na wprowadzenie innowacji.

2. Innowacja musi mieć charakter konceptualny i perceptualny, czyli powinna „wychodzić naprzeciw” lub inaczej spełniać oczekiwania i potrzeby klientów i użytkowników innowacji. Realizacja tego wymogu niesie za sobą konieczność przeprowadzenia prac analitycznych (poszukiwania, pytania, słuchania) określających warunki przebiegu tego procesu.

3. Innowacja musi być prosta i jasno określona, czyli zrozumiała i niestwarzająca wieloznaczności.

4. Ponadto powinna zaczynać się skromnie, nie angażując zbyt wielu ludzi i celując w mały „rynek”, ponieważ konieczne zmiany (na początku każda innowacja jest jedynie ,prawie dobra”) mogą być wprowadzone tylko wtedy, gdy skala działań jest jeszcze niewielka, a oczekiwania co do angażowania ludzi i środków - skromne.

5. Osiągnięcie przez innowację wiodącej pozycji w danym otoczeniu. Jest to możliwe, jeżeli innowacja będzie ważna dla jej użytkowników i nie stworzy szansy dla konkurencji.

Zdaniem Druckera celowe innowacje są efektem analiz istniejących systemów i ciężkiej pracy - ta grupa stanowi co najmniej 90\% wszystkich efektywnych innowacji. Badacz dodatkowo podkreśla, że tylko takie działania warto przedstawiać jako ,innowacyjne praktyki” (Drucker, 2002, s. 404). Można przyjąć za Druckerem, że kluczowe miejsce zajmuje tu wiedza, która jest współcześnie powszechnie dostępna. Dobrą konkluzją są też jego słowa: „Nie będzie już krajów »biednych«. Będą tylko zacofane i niedouczone” (Drucker, 2002, s. 23). W przypadku pracy szkoły:

(...) większość innowacji, zwłaszcza tych istotnych - o uniwersalnym znaczeniu i dużej randze kulturotwórczej - powstaje na ogół „na zewnątrz” działającego podmiotu. (...) Oznacza to, że procesy polegające na pionierskiej adopcji „,cudzych” innowacji mają - ilościowo rzecz ujmując - prymat nad zjawiskami samodzielnego tworzenia i przyswajania przez nauczycieli nowych rozwiązań. (Schulz, 1994, s. 85)

To specyficzna sytuacja, w której ten, kto tworzy (projektuje daną innowację), nie musi być jej wyłącznym odbiorcą. 
Innowacje w edukacji i uczeniu się (innovation in education, innovation in learning) zachodzą w specyficznym kontekście realizowanych procesów nauczania i uczenia się, udoskonalając standardową praktykę lub wprowadzając nową, dzięki czemu uczniowie (szkoły) uzyskują wyższe osiągnięcia i poprawiają efektywność uczenia się (Redding, Twyman, Murphy, 2013, s. 6). Konieczność uzyskania poprawy, jak dowodzą Kieron Kirkland i Dan Sutch (2009, s. 10), wynika z określenia, że ,innowacja to zastosowanie nowego zasobu lub podejścia, które zmienia praktykę społeczną, tworząc pewną wartość". Oznacza to, że nowe osiągnięcie jest lepsze lub bardziej efektywne niż poprzednie (Licht, Tasiopoulou, Wastiau, 2017, s. 15). W odniesieniu do szkoły to lepsze lub bardziej efektywne osiągnięcie musi mieć związek z poprawą uczniowskich dokonań i jest to niezbywalny warunek wskazywany przez ekspertów OECD, by mówić o innowacjach w edukacji. Przyjęcie warunku poprawy uczniowskich osiągnięć można odczytać jako odniesienie do „Schumpeterowskiego” zastosowania danego rozwiązania (produktu/wynalazku) w praktyce, tu w praktyce edukacyjnej, realizującej misję szkoły i sens edukacji.

Innowacje można również interpretować jako „podniesienie zdolności adaptacyjnych systemu oświatowego" (Licht i in., s. 58). Wówczas ważnym jej aspektem, który warto rozważyć, jest kategoria zmiany; należy też wykazać brak równości między innowacją a zmianą. Mimo że każda innowacja jest zmianą, to jednak nie każda zmiana jest innowacją. W wielostronnych i wieloaspektowych przeobrażeniach, jakie dokonują się w instytucjonalnej praktyce edukacyjnej, możliwe jest odszukanie wielu typów zmian. Bezsprzecznie celowe zmiany wprowadzane do praktyki szkolnej mogą inicjować proces modernizacji i wprowadzać innowacje, choć i tu istnieje niebezpieczeństwo zaistnienia zmian nieobejmujących „fundamentów systemu i poza ich zasięgiem pozostaną schematy interpretatywne" lub okażą się ,regresywne, pojmowane jako cofnięcie się w systemie edukacyjnym do rozwiązań z przeszłości (sprawdzonych lub zdezaktualizowanych), do tego, co już było, oraz zmiany adaptacyjne (...), w których do starych rozwiązań dodawane są nowe bądź też pewne dawne struktury zostają zastąpione nowymi, zmodyfikowanymi rozwiązaniami" (Śliwerski, 2008, s. 110). Zmiany te można uznać za powierzchowne, zmienia się w nich bowiem ,szkołę czy edukację jedynie po to, by nic istotnego w niej nie uległo zmianie" (Śliwerski, 2008, s. 111).

Zasadnicza różnica pomiędzy innowacją i zmianą wyłania się z racjonalności, rzeczywistości i progresywnego charakteru tej pierwszej, jeśli przyjmiemy sposób interpretacji Schumpetera. Innowacje w edukacji mają się przyczyniać do wzrostu uczniowskich osiągnięć i poprawy pracy szkoły, co z założenia stanowi ich cel. Większość literatury przedmiotu definiuje innowację jako implementację nie tylko nowych pomysłów, wiedzy i praktyk, lecz także ulepszonych pomysłów, wiedzy i praktyk (Kostoff, 2003). Innowacja jest zatem ewidentnie odmienna od 
zmian, które niekoniecznie oznaczają zastosowanie czegoś nowego ani nie implikują zastosowania ulepszonych pomysłów czy wiedzy (King, Anderson, 2002). Można przyjąć, że ignorowanie tego faktu i uproszczenie czy też równoważne traktowanie innowacji i zmiany przynosi szkole więcej szkody niż pożytku.

\section{PRZEDSIĘBIORCZOŚĆ JAKO ZDOLNOŚĆ INNOWACYJNA SZKOŁY}

Zmiany praktyki szkolnej możliwe są w wyniku zmian dogłębnych, które wyłaniają nowe role społeczne, nowe potrzeby i oczekiwania (Radziewicz-Winnicki, 1999, s. 190). Wówczas na znaczeniu zyskują wspólne cele i zasady postępowania członków tej zbiorowości. Zdaniem badaczy problemu „zmiana struktur bez zmiany świadomości prowadzi do powstania sfery pozoru, do konstruowania bytów funkcjonujących w nierozpoznany i nieprzewidziany sposób" (Szkudlarek, 2000, s. 288).

Warto w tym miejscu podkreślić, że zdolność do zmiany, do nieustającego rozwoju jest fundamentem, na którym naukowcy opierają nowe koncepcje szkoły i eksponują potencjał kultury organizacyjnej. W swoich wywodach podejmują się tym samym redefinicji jakości uczenia się celem sprostania potrzebom młodych ludzi i społeczeństwa w świecie ciągłych wyzwań. Podejście takie angażuje społeczność szkolną w proces inicjowania celowych zmian i zarazem zwiększa kontrolę nad treścią i tempem ich wprowadzania. Można przyjąć, że tworzenie w szkole nowej jakości ,jest procesem rozpoznawania nowych potrzeb, uczenia się poprzez doświadczenie, tworzenia nowej praktyki i nabywania biegłości we wspólnym działaniu" (Dalin, za: Hildebrandt, 2001, s. 74). W efekcie tego szkoła, rozpatrując stawiane przed nią wymagania, czyni to w świetle własnej wizji i misji, kreując w ten sposób swoją przyszłość. Podejście to eksponuje znaczenie bezpośredniego zaangażowania wszystkich pracowników szkoły i uczniów w określanie potrzeb oraz ustanawianie celów programu rozwoju placówki jako warunku samoistnej i autentycznej odnowy szkoły (Nowosad, 2003). W takim ujęciu eksponowane jest znaczenie tworzenia w szkole kultury przedsiębiorczej jako wzmacnianie innowacyjnej zdolności placówki.

Kultura szkoły zorientowana na przedsiębiorczość może być rozumiana jako układ wspólnych, naczelnych przesłanek, których zespół wyuczył się pokonywania problemów związanych z adaptacją zewnętrzną oraz wewnętrzną integracją. Układ ten zdołał się obronić i obowiązuje jako wiążący (Schein, 1995, s. 25). W kulturze przedsiębiorczej reguły są stabilne i określają, jak społeczność szkolna powinna reagować na zmiany otoczenia (adaptacja zewnętrzna) oraz jak ukierunkować wszystkie siły w szkole na wspólny cel (integracja wewnętrzna).

Szczególnym aspektem kultury przedsiębiorczej jest stopień jej otwartości. Im bardziej szkoła jest otwarta, tzn. im więcej jest w niej miejsca na nowe idee, aktywne współtworzenie i inicjatywy członków społeczności, tym większa jest 
jej siła innowacyjna. Jednak przy dużej otwartości placówki potrzebne są dodatkowe środki mające na celu wspieranie mocy innowacyjnej (np. jasne wytyczne celów i reguł działania). To zapewnia orientację, przewidywalność zachowań innych, a poprzez to umacnia zaufanie do kierownictwa szkoły i współpracowników. Możliwe konflikty między członkami organizacji, jakie mogą się pojawić na skutek zbyt dużej otwartości, można wówczas uniknąć, ponieważ łatwiej jest je pokonać za pomocą adekwatnych środków integrujących. Można zatem przyjąć, że znacząca (wysoka) zdolność innowacyjna może być osiągnięta przez jednoczesne otwarcie i integrację w szkole jako organizacji. Realizacja tego ma miejsce poprzez zastosowanie różnych form współuczestnictwa wszystkich podmiotów i wzmacnianie procesów uczenia się jako strategii wprowadzania zmian.

Zagadnienie zmiany i radzenia sobie z nią przez społeczność szkolną stanowi fundament, na którym budowane są nowe rozwiązania, a jednym $\mathrm{z}$ nich jest model szkoły jako „uczącej się organizacji”. Model ten został opracowany przez Petera Senge i sprowadza się do trzech obszarów: myśli przewodnich, innowacji w infrastrukturze oraz metod i narzędzi, które można w analogiczny sposób przenieść na szkołę. Myśli przewodnie uzyskują miano programu szkoły. Do innowacji $\mathrm{w}$ infrastrukturze należą nowe struktury kooperacyjne i sterowanie procesem oraz obszar metod i technik zorientowanych na rozwój i poprawę pracy szkoły. W ujęciu tym szkoła przestaje być instytucją, w której uczą się uczniowie. Jest bowiem zdolna do zmiany i nieustającego rozwoju po to, by sprostać nowym wymaganiom sytuacyjnym zachodzącym w szybko zmieniającym się społeczeństwie. W przyjętym rozumieniu szkoła ma do odegrania niepowtarzalną rolę w definiowaniu jakości uczenia się, co sprawia, że zawsze powinna rozpatrywać stawiane przed nią wymagania w świetle własnej wizji i misji, kreując w ten sposób swoją przyszłość. Należy jednak w tym miejscu zwrócić uwagę, że samoistna i autentyczna odnowa szkoły zwykle wymaga bezpośredniego zaangażowania wszystkich jej pracowników oraz rodziców i uczniów w określanie potrzeb i ustanawianie celów programu rozwoju, czyli w działania wspólnotowe nacechowane współpracą. Tym samym szkoły jako „uczące się organizacje” usprawiedliwiają stawiane żądania o zwiększenie obszaru samodzielności szkoły, gdyż - jak to uzasadnia Per Dalin - przyjęcie takiego punktu widzenia jest możliwe jedynie przy formalnie ugruntowanej autonomii. Według niego poziom autonomii szkoły wobec państwa jest istotnym czynnikiem wykorzystującym strategię rozwoju organizacyjnego dla jej odnowy (Nowosad, 2003).

W uczących się szkołach przeplata się pielęgnacja własnej kultury i wydolności uczenia $z$ tworzeniem na nowo własnych podstaw. Wewnątrz tej specyficznej organizacji dotyczy to z jednej strony kadry nauczycielskiej, dla której Michael Fullan wyznaczył pojęcie „,nauczyciela uczącego się”, a z drugiej strony odnosi się do szkoły jako organizacji, która świadomie się rozwija, uczy swoje szkolne grono objaśniania, wspólnego diagnozowania mocnych i słabych stron, 
ustalania priorytetów w rozwoju, tworzenia zespołów, zarządzania projektami i oceniania efektywności tych nowatorskich pomysłów. Niewątpliwie taka organizacja nacechowana jest wysoce rozwiniętymi mechanizmami autoewaluacji, lecz bezsprzecznie może to być osiągnięte poprzez zwiększenie kompetencji komunikacyjnych oddziałujących na kulturę interakcyjną, która sprawia, że problemy, z jakimi szkoła musi się zmierzyć, będą do pokonania. Na każdym poziomie „,zetknięcia się" z problemem priorytetowego znaczenia nabierają relacje pomiędzy członkami społeczności szkolnej i wolą współpracy, ponieważ to poprzez dialog i rzeczywiste wzajemne oddziaływania rozpowszechniają się procesy zmian.

Usprawnienie pracy szkoły zakłada zatem zmianę jej kultury, pewnego porządku symbolicznego: od fragmentarycznego indywidualizmu, w którym tkwiący w „świątyni klasy lekcyjnej” nauczyciel odseparowany jest od wpływów zewnętrznych, do kultury współpracy, przez wzajemne wsparcie i wspólną pracę. Współpraca zwraca uwagę na innowacyjny potencjał, jaki tkwi w konkretnej szkole, i eksponuje go w swoich działaniach. Wówczas założenia i uwarunkowania procesów interakcyjnych i komunikacyjnych w szkole jako organizacji społecznej awansują do rangi centralnych zagadnień reformowania instytucji oświatowych. Przyjmując za punkt wyjścia takie podejście, do zadań szkoły należałoby zaliczyć: uzgadnianie celu, planowanie zadań, przydzielanie czynności, koordynację (kto, co, kiedy, jak), kontrolę, osiągnięcie konsensusu, regulacje w sprawach spornych. Wymienione tu obszary działań eksponują czynności programowe, które mają zainicjować wewnętrzną przemianę szkoły, lecz równie ważna okazuje się sfera stosunków interpersonalnych - tak w ramach rady pedagogicznej, jak i pozostałych podmiotów edukacji szkolnej - oraz sfera podnoszenia kwalifikacji nauczycieli (rozwój szkoły może się dokonywać tylko i wyłącznie, jeśli $\mathrm{w}$ ten proces jest włączony rozwój kadry pedagogicznej).

Łączne traktowanie procesów zmian programowych, stosunków interpersonalnych i podnoszenia kwalifikacji personelu pedagogicznego kieruje uwagę na planowane przemiany szkoły zgodne z założeniami rozwoju organizacyjnego, w którym na znaczeniu zyskuje rozwój organizacji od środka. Wówczas proces uczenia się ludzi i organizacji uznawany jest za tożsamy.

W procesie rozwoju przedsiębiorczej kultury organizacyjnej szkoły można wyróżnić pięć głównych następujących po sobie faz (tabela 1).

Pierwsza faza: Diagnoza.

Cel: Kształtowanie „kultury idealnej” w obliczu istniejących warunków, które wyznaczają kierunek przyszłych kroków kształtowania kultury i dobór adekwatnych instrumentów.

Przebieg: Pierwsza faza obejmuje trzy etapy:

1. Przeprowadzenie warsztatów, podczas których kierownictwo opracowuje wspólnie z podmiotami społeczności szkolnej cechy kultury idealnej dla danej szkoły. 
Tabela 1. Innowacje w rozwoju szkoły

\begin{tabular}{|c|l|}
\hline \multicolumn{2}{|c|}{ Kultura zaufania, błędów, uczenia się i innowacji } \\
\hline Diagnoza & $\begin{array}{l}\text { 1. Wzniesienie ideału (uczenie się i wiedza, komunikacja) } \\
\text { 2. Ujęcie (zdefiniowanie) rzeczywistości w odniesieniu do ideału (uczenie się, } \\
\text { wiedza, komunikacja) } \\
\text { 3. Opis rozbieżności między ideałem a rzeczywistością }\end{array}$ \\
\hline Interwencja & $\begin{array}{l}\text { 1. Dobór i użycie skutecznych środków w celu zredukowania rozbieżności } \\
\text { pomiędzy ideałem a rzeczywistością } \\
\text { 2. Realizacja sieciowych interwencji w poszczególnych obszarach }\end{array}$ \\
\hline Prewencja & $\begin{array}{l}\text { 1. Dobór i zastosowanie środków prewencyjnych w odniesieniu do komponentów: } \\
\text { uczenie się i wiedza }\end{array}$ \\
\hline Innowacja & $\begin{array}{l}\text { 1. Dobór wskaźników do zdefiniowania innowacyjności } \\
\text { 2. Dobór i użycie metod wspomagających innowacje w obliczu komponentów: } \\
\text { uczenie się i wiedza oraz komunikacja }\end{array}$ \\
\hline Kontrola & $\begin{array}{l}\text { 1. Opracowanie wskaźników innowacyjności } \\
\text { 2. Ewaluacja efektywności. Skuteczność i systemowa zgodność metod rozwoju szkoły }\end{array}$ \\
\hline \multicolumn{1}{|c|}{ Asysta, nadzór procesu i zrównoważone zarządzanie } \\
\hline
\end{tabular}

Źródło: opracowanie własne na podstawie: (Reick, Kastner, s. 491).

2. Określenie faktycznego wpływu kultury w poszczególnych obszarach pracy szkoły.

3. Zrównanie pożądanej kultury idealnej z faktyczną, rzeczywistą kulturą, zastaną w szkole.

Metodyka: W zakresie pierwszej fazy są możliwe następujące metody:

- krok pierwszy: niezależny moderator przeprowadza warsztaty w celu rozwinięcia (zaprojektowania) kultury idealnej,

- $\quad$ krok drugi: zastosowanie narzędzi pomiaru (ankieta), które mogą być uzupełnione wywiadami.

Druga faza: Interwencja.

Cele: Dobór, względnie opracowanie specyficznych zabiegów (środków, kroków) w celu zredukowania rozbieżności między idealnym a rzeczywistym wpływem kultury. Dopasowanie środków do każdego obszaru pracy szkoły.

Przebieg: Przeprowadzenie warsztatów, w trakcie których zostaną opracowane metody, dzięki którym zniweluje się różnice między idealnymi a rzeczywistymi cechami kultury. Ustalenie ram czasowych oraz drogi do osiągnięcia celu.

Metodyka: Możliwe są różne metody:

- zespolenia uczestników (np. koła uczenia się i kooperacji, model z mentorem, partnerstwo w nauce),

- dydaktyczne (wprowadzenie mediów, np. seminarium albo coaching),

- $\quad$ przekazu wiedzy i rozwoju nowych idei oraz nowej wiedzy (np. analiza najlepszych praktycznych przykładów, badania wybranego przypadku, techniki kreatywności), 
- sprawdzające skuteczność (np. ankiety i krótkie standaryzowane wywiady).

Trzecia faza: Prewencja.

Cel: Rozwój i implementacja środków, które powinny zagwarantować śmiałe wyjście naprzeciw problemom możliwym do zaistnienia w przyszłości.

Przebieg: Zorganizowanie warsztatów, podczas których uczestnicy opracowują prewencyjne metody zapobiegające zakłóceniu bądź blokadzie planowanego przekształcania kultury.

Metodyka: Szkolenia przy zastosowaniu technik pracy z małymi grupami oraz grupowe dyskusje z moderatorem. Scenariusz „możliwie najgorszego przypadku", w którym zostaną przewidziane potencjalne blokady i przeszkody w przebiegu rozwoju kultury oraz zostaną opracowane dla nich rozwiązania.

Czwarta faza: Innowacja.

Cel: Zaprojektowanie nowych środków, które będą sprzyjać różnorodności w szkołach, a ta będzie wykorzystywana jako ważne źródło dla innowacji.

Przebieg: Realizacja szkoleń ukierunkowanych pytaniem: Co możemy uczynić, aby w przyszłości uniknąć problemów i dalej się rozwijać? Opracowanie nowatorskich technik.

Metodyka: Warsztaty przyszłości, koła nowatorskie, zespoły ekspertów, dydaktyka wspierająca kreatywność.

Piąta faza: Kontrola (asysta, nadzór procesu i zrównoważone zarządzanie).

Cel: Kierowanie i kontrola skuteczności (efektywności) wcześniej zaprojektowanych i wprowadzonych środków rozwoju kultury. Gwarancja ich realizacji i zapobiegania efektu ,utknięcia” zmian.

Przebieg: Ciągła asysta oraz nadzór procesów i środków, które wprowadzono w ramach faz od fazy drugiej, w odniesieniu zarówno do poszczególnych osób (płaszczyzna jednostkowa), jak i całej społeczności (płaszczyzna zespołowa).

Metodyka: Refleksja nad rozwojem kultury z poszczególnymi członkami społeczności szkolnej oraz w grupach (dyskusje w zespołach z moderatorem). Identyfikacja faktorów, które blokują przeprowadzenie interwencji albo okazują się trudne przy wdrażaniu zmian (np. przez „wywiady głębi” z ekspertami).

\section{ZAKOŃCZENIE}

Centralne miejsce innowacji $\mathrm{w}$ debatach polityczno-oświatowych wyraża troskę o skuteczność i efektywność kształcenia odpowiadającego na współczesne wyzwania globalizacji, które burzą dotychczasową wizję dobrze zorganizowanego świata i kierują uwagę na konieczność uwzględniania dynamiki i spontaniczności zjawisk. W rzeczy samej udana innowacja zależy od ludzkiej kreatywności, wiedzy, umiejętności i talentów, które w dużej mierze są rozwijane przez edukację, a przynajmniej powinny być. Kluczowego znaczenia nabiera zatem rozpo- 
znanie, w jaki sposób szkoły i nauczyciele mogą lepiej kultywować te zdolności, a w dalszej kolejności - praktykowanie innowacji. W efekcie rozwijana jest zdolność innowacyjna szkoły, która determinuje kształtowanie w szkole kultury przedsiębiorczości i w jej ramach społeczności otwartej na podejmowanie ryzyka. Jednakże warto mieć na uwadze, że nie każda zmiana jest dla szkoły ważna czy potrzebna. Fullan (2016) zauważa, że mamy tendencję do reagowania reorganizacją na dowolną sytuację i jest to wspaniała metoda na stworzenie iluzji postępu². W efekcie prowadzi bowiem do zwątpienia, powoduje brak efektywności i wzbudza demoralizację w środowisku nauczycieli kultywujących grę pozoru bez namysłu uznających wszystko, co dla nich nowe, za innowacje. $Z$ tego choćby powodu zrozumienie istoty innowacji nabiera kluczowego znaczenia, stając się warunkiem inicjowania procesów zorientowanych na rozwój szkoły i postęp.

\section{BIBLIOGRAFIA}

Adamczyk, W. (1995). Przedsiębiorczość. Próba definicji. Przegląd Organizacyjny, 11, 11-15.

Drucker, P.F. (1992). Innowacja i przedsiębiorczość. Praktyka i zasady. Warszawa: PWE.

Drucker, P.F. (2002). Myśli przewodnie Druckera. Warszawa: MT Business.

Encyklopedia powszechna. (1997). Warszawa: PWN.

Fayolle, A., Gailly, B., Lassas-Clerc, N. (2006), Effect and Counter-Effect of Entrepreneurship Education and Social Context on Student's Intentions. Estudios de Economía Aplicada, 24(2), 509-523.

Fayolle, A., Gailly, B. (2008). From craft to science. Teaching models and learning processes in entrepreneurship education. Journal of European Industrial Training, 32(7), 569-593,

DOI: https://doi.org/10.1108/03090590810899838.

Fullan, M. (2016). Indelible Leadership: Always Leave Them Learning. Thousand Oaks: Corwin Press.

Fullan, M., Hargreaves, A. (2016). Bringing the Profession Back In: Call to Action. Oxford: Learning Forward.

Fullan, M., Quinn, J. (2016). Coherence: The Right Drivers in Action for Schools, Districts, and Systems. Thousand Oaks: Corwin Press.

Garavan, T.N., O'Cinneide, B. (1994). Entrepreneurship education and training programmes: A review and evaluation. Journal of European Industrial Training, 18(8), 3-12,

DOI: https://doi.org/10.1108/03090599410068024.

Gołdyka, L. (1999). Przedsiębiorczość jako przedmiot zainteresowań w socjologii. W: L. Gołdyka, D. Markowska, J. Stankiewicz (red.), Socjologia. Pojęcia, teorie, problemy (s. 221-234). Zielona Góra: Wydawnictwo Politechniki Zielonogórskiej.

2 Krytyczne uwagi Fullana dotyczące niewłaściwego rozumienia innowacji w edukacji i opierania na tym procesu przemiany szkoły można odszukać także w innych jego pracach (zob. Fullan, Hargreaves, 2016; Fullan, Quinn, 2016). 
Gürol, Y., Atsan, N. (2006). Entrepreneurial characteristics amongst university students. Education + Training, 48(1), 25-38, DOI: http://dx.doi.org/10.1108/00400910610645716.

Hasło: przedsiębiorczość. W: Encyklopedia zarządzania. Pobrane z: https://mfiles.pl/pl/index.php/ Przedsi\%C4\%99biorczo\%C5\%9B\%C4\%87 (dostęp: 10.08.2019).

Hildebrandt, A. (2001). Koncepcja rozwoju organizacyjnego szkoły Pera Dalina. W: E. Potulicka (red.), Szkice z teorii i praktyki zmiany oświatowej (s. 61-138). Poznań: Wydawnictwo Eruditus. Janowski, A. (1998). Stownik ekonomiczny. Kraków: Wydawnictwo Instytutu GSMiE.

Karney, H. (2007). Psychopedagogika pracy. Warszawa: Wydawnictwo Akademickie „Żak”.

King, N., Anderson, N. (2002). Managing Innovation and Change: A Critical Guide for Organizations. London: Thompson.

Kirby, D.A. (2004). Entrepreneurship education: Can business schools meet the challenge? Education + Training, 46(8/9), 510-519, DOI: https://doi.org/10.1108/00400910410569632.

Kirkland, K., Sutch, D. (2009). Overcoming the Barriers to Educational Innovation. Bristol: Futurelab.

Koch, R. (1997). Stownik zarzadzania i finansów. Narzędzia, terminy, techniki od A do Z. Kraków: Wydawnictwo Profesjonalnej Szkoły Biznesu.

Kortana, J. (red.). (1997). Podstawy ekonomiki i zarządzania przedsiębiorstwem. Warszawa: C.H. Beck.

Kostoff, R.N. (2003). Stimulating innovation. W: L.V. Shavinina (ed.), The International Handbook on Innovation (s. 388-400). London: Pergamon.

Kuratko, D.F. (2003). Entrepreneurship education: emerging trends and challenges for the $21^{\text {st }}$ century. Chicago: White Papers Series, Coleman Foundation.

Kwiatkowski, S. (2000). Przedsiębiorczość intelektualna. Warszawa: PWN.

Licht, A.H., Tasiopoulou, E., Wastiau, P. (2017). Open Book of Educational Innovation. Brussels: European Schoolnet.

Looney, J.W. (2009). Assessment and Innovation in Education. OECD Education Working Papers, 24, DOI: http://dx.doi.org/10.1787/222814543073.

Nowosad, I. (2003). Perspektywy rozwoju szkoty. Warszawa: IBE.

Nowosad, I. (2008). Autonomia szkoły publicznej w Niemczech. Poszukiwania, konteksty, uwarunkowania. Zielona Góra: Oficyna Wydawnicza Uniwersytetu Zielonogórskiego.

Przyborowska, B. (2013). Pedagogika innowacyjności. Między teoria a praktyka. Toruń: Wydawnictwo UMK.

Radziewicz-Winnicki, A. (1999). Modernizacja niedostrzegalnych obszarów rodzimej edukacji. Kraków: Oficyna Wydawnicza Impuls.

Redding, S., Twyman, J.S., Murphy, M. (2013). What is an innovation in learning? W: M. Murphy, S. Redding (eds.), Handbook on Innovations in Learning (s. 133-148). Philadelphia: Center on Innovations in Learning, Temple University, Charlotte, Information Age Publishing.

Reick C., Kastner, M. (2006). Innovation durch Kulturentwicklung - Vertrauensfehlerlerninnovationsgesundheitskultur als Konzept innovativer Organisationsentwicklung. W: Innovationen für Arbeit und Organisation. Dokumentation des 52 Arbeitswissenschaftlichen Kongresses in Stuttgart, Dortmund: GfA-Press. 
Schein, E. (1995). Unternehmenskultur. Ein Handbuch für Führungskräfte. Frankfurt am Main: Campus.

Schulz, R. (1994). Twórczość pedagogiczna. Elementy teorii i badań. Warszawa: IBE.

Szkudlarek, T. (2000). Radykalna krytyka i pragmatyczna zmiana. W: Z. Kwieciński (red.), Alternatywy myślenia o/dla edukacji (s. 277-278). Warszawa: IBE.

Śliwerski, B. (2008). Oświatowy remanent, czyli o ideologicznym majsterkowaniu polityków oświatowych w latach 1989-2006. W: M. Dudzikowa, M. Czerepaniak-Walczak (red.), Wychowanie. Pojęcia-procesy - konteksty (T. 4; s. 95-140). Gdańsk: GWP.

Tucker, D., Selcuk, S. (2009). Which factors affect entrepreneurial intention of university students? Journal of European Industrial Training, 33(2), 142-159,

DOI: https://doi.org/10.1108/03090590910939049.

\section{SUMMARY}

The changes that are taking place in and around school have become a challenge for its functioning. The article focuses on two categories: innovation and entrepreneurship, which are analysed as crucial not only in preparing pupils to enter into adulthood, including their professional life, but also as a precondition for the renewal of school itself. When reviewing both Polish and foreign literature, some arguments are invoked that are meant to justify the position adopted by the author.

Keywords: innovation; entrepreneurship; school development 